\title{
Pengaruh Fly Ash Terhadap Kuat Tekan dan Porositas Beton Berpori
}

\author{
The Effect of Fly Ash on the Compressive Strength and Porosity of Porous Concrete
}

\author{
Bernaditha Catur Marina ${ }^{1, *}$, Dika Ahmad Pujiyanto ${ }^{1}$ \\ ${ }^{1}$ Teknik Sipil, Institut Teknologi Sumatera, Jl. Terusan Ryacudu, Way Huwi, Lampung Selatan
}

\author{
*Penulis korespondensi : bernaditha@si.itera.ac.id \\ Tel.:+62-81310854814; fax.:- \\ Diterima: 22 September 2020; Direvisi: 29 Oktober 2020; Disetujui: 30 Oktober 2020. \\ DOI: 10.25299/saintis2020.vol20(02).5622
}

\begin{abstract}
Abstrak
Peningkatan penggunaan beton konvensional mengakibatkan lapisan kedap air semakin luas, yang berimbas kepada turunnya muka air tanah dan terjadi banjir pada musim hujan. Hal ini dapat disiasati salah satunya melalui pengaplikasian cara-cara pembangunan yang ramah lingkungan, seperti penggunaan fly ash. Tujuan penelitian kali ini adalah untuk mengetahui presentase fly ash pada campuran beton agar menghasilkan kuat tekan dan porositas optimum. Pada penelitian ini digunakan fly ash sebagai bahan tambahan campuran dengan variasi sebesar $0 \%, 10 \%$, dan $20 \%$ dari berat semen dan variasi faktor air semen (FAS) yang digunakan sebesar 0,3, 0,4, 0,5. Agregat kasar berukuran maksimum $20 \mathrm{~mm}$, dengan jumlah sampel 36 buah silinder, 27 buah silinder untuk pengujian kuat tekan dan 9 buah silinder untuk pengujian porositas dilakukan pada usia 28 hari. Mutu beton rencana pada penelitian ini 10 MPa mengacu pada mutu bata beton. Pengujian kuat tekan beton yang dihasilkan menggunakan alat CTM (Compression Testing Machine) dan pengujian porositas menggunakan alat Falling Head Water Permeability Test yang megacu pada ACI 522R-10 yang dimodifikasi. Hasil ekperimen menunjukan nilai optimum kuat tekan dan porositas rata-rata dengan variasi FAS 0,3 : FA 10\%, untuk umur beton 28 hari secara berturut-turut adalah 5,4 MPa dan 7,75 m3/s. Kesimpulan penelitian ini adalah komposisi paling optimum untuk penggunaan fly ash yaitu sebesar $10 \%$ dengan faktor air semen 0,3 .
\end{abstract}

Kata kunci: beton berpori, fly ash, kuat tekan, porositas

\section{Abstract}

The increase in the use of conventional concrete resulted in a wider airtight layer, which resulted in the lowering of the groundwater level and flooding during the rainy season. One of the ways to overcome this is through the application of environmentally friendly development methods, such as the use of fly ash. The purpose of this research was to determine the percentage of fly ash ih concrete mixture to produce optimum compressive strength and porosity. In this study, fly ash was used as an additional mixture with variations of $0 \%, 10 \%$, and $20 \%$ of the weight of cement and variations of the cement water factor (FAS) used were 0.3, 0.4, 0.5. The maximum size of coarse aggregate is $20 \mathrm{~mm}$, with a sample size of 36 cylinders, 27 cylinders for compressive strength testing and 9 cylinders for porosity testing carried out at the age of 28 days. The quality of the concrete plan in this study is $10 \mathrm{MPa}$ which refers to the quality of the concrete brick. Testing the compressive strength of the concrete produced using a CTM (Compression Testing Machine) and porosity testing using the Falling Head Water Permeability Test which refers to the ACI 522R-10. The experimental results showed that the optimum compressive strength and average porosity with FAS variation of 0.3: FA 10\%, for 28 days of concrete were $5.4 \mathrm{MPa}$ and $7.75 \mathrm{~m} 3$

Keywords: porous concrete, fly ash, compressive strenght, porosity

\section{PENDAHULUAN}

Penggunaan beton konvensional yang terus meningkat mengakibatkan lapisan kedap air semakin luas, sehingga air hujan tidak dapat berinfiltrasi kedalam tanah dan mengakibatkan limpasan permukaan (surface runoff) menjadi lebih besar. Hal ini mengakibatkan muka air tanah menjadi turun dan terjadi genangan atau banjir pada musim hujan. Salah satu cara yang dapat dilakukan dalam bidang konstruksi untuk menyelesaikan masalah ini adalah dengan cara-cara pengaplikasian pembangunan yang ramah lingkungan sehingga dilakukan banyak penelitian serta uji coba untuk mencari metode yang baik dengan produk konstruksi yang ramah lingkungan. Salah satu hasil dari penelitian yang dilakukan untuk merealisasikan konstruksi ramah lingkungan adalah menggunakan limbah fly ash sebagai bahan campuran pengganti semen dalam pembuatan beton berpori. Demikian sebaliknya semen dapat juga digunakan sebagai pengganti fly ash [1].

Beton berpori adalah jenis beton khusus dengan porositas tinggi yang diaplikasikan sebagai plat beton yang memungkinkan air hujan dan air dari sumber-sumber lain untuk dapat melewatinya, sehingga mengurangi limpasan permukaan dan 
meningkatkan muka air tanah. Porositas tinggi tercapai karena rongga yang saling berhubungan. Biasanya beton berpori menggunakan sedikit atau tanpa agregat halus dan memiliki cukup pasta semen untuk melapisi permukaan agregat kasar dan untuk menjaga interkonektivitas pori. Beton berpori secara tradisional digunakan untuk area parkir, di daerah lampu lalu lintas, dan trotoar untuk pejalan kaki [2].

Di provinsi Lampung pemanfaatan limbah indrustri dan PLTU masih belum banyak di manfaatkan sehingga perlu dimanfaatkan supaya dapat mengurangi pencemaran terhadap lingkungan, oleh karena itu digunakan limbah fly ash pada penelitian kali ini dikarenakan fly ash merupakan satu bahan tambah (additive) yang cukup populer saat ini untuk digunakan sebagai bahan pengganti sebagian semen dalam campuran beton dan sebagai bahan untuk stabilisasi tanah ekspansif. Pemanfaatan fly ash membawa manfaat ekologi dan ekonomi, diantaranya yang terpenting adalah pengurangan bahan limbah dan penghematan energi [3] .

Tujuan dari penelitian ini yaitu: untuk mengetahui pengaruh penambahan fly ash terhadap kuat tekan dan porositas beton berpori; untuk mengetahui persentase fly ash pada campuran beton yang menghasilkan kuat tekan dan porositas optimum.

Pada penelitian ini digunakan fly ash sebagai bahan tambahan campuran dengan variasi sebesar $0 \%$, 10\%, dan $20 \%$ dari berat semen dan variasi faktor air semen (FAS) yang digunakan sebesar 0,3, $0,4,0,5$. Agregat kasar berukuran maksimum 20 mm, dengan jumlah sampel 36 buah silinder, 27 buah silinder untuk pengujian kuat tekan dan 9 buah silinder untuk pengujian porositas dilakukan pada usia 28 hari.

\section{METODOLOGI}

Pada penelitian ini metode yang digunakan yaitu metode eksperimen. Penelitian ini bermaksud untuk menguji pengaruh fly ash terhadap beton berpori. Benda uji yang digunakan untuk penelitian kuat tekan dan porositas beton berpori yaitu berbentuk silinder dengan ukuran diameter $15 \mathrm{~cm}$ dan tinggi $30 \mathrm{~cm}$. Adapun tahapan penelitian digambarkan pada Gambar 1.

\section{Persiapan Material}

Pada tahap persiapan material ini seluruh bahan-bahan campuran beton dan peralatan yang dibutuhkan dipersiapkan seperti:

1. Semen Portland

Semen yang digunakan adalah semen Tipe 1 PCC (Portland Composit Cement) dengan label Semen Padang. Fungsi utama semen adalah mengikat butir-butir agreagat hingga membentuk suatu massa padat dan mengisi rongga-rongga udara diantara butir-butir agregat. Walaupun komposisi semen dalam beton hanya sekitar 10\%, namun karena fungsinya sebagai bahan pengikat maka peranan semen menjadi penting [4].

2. Agregat Kasar

Agregat kasar yang digunakan dalam penelitian ini adalah batu pecah yang berasal dari Sumber Batu Berkah, Lampung Selatan [5], [6].

3. Air

Air yang digunakan berasal dari instalasi air bersih Laboratorium Bahan dan Konstruksi, Institut Teknologi Sumatera (ITERA)

4. Fly ash (Abu terbang)

Fly ash (abu terbang) adalah material yang berasal dari sisa pembakaran batu bara yang tidak terpakai berasal dari PLTU Tarahan, Lampung Selatan.

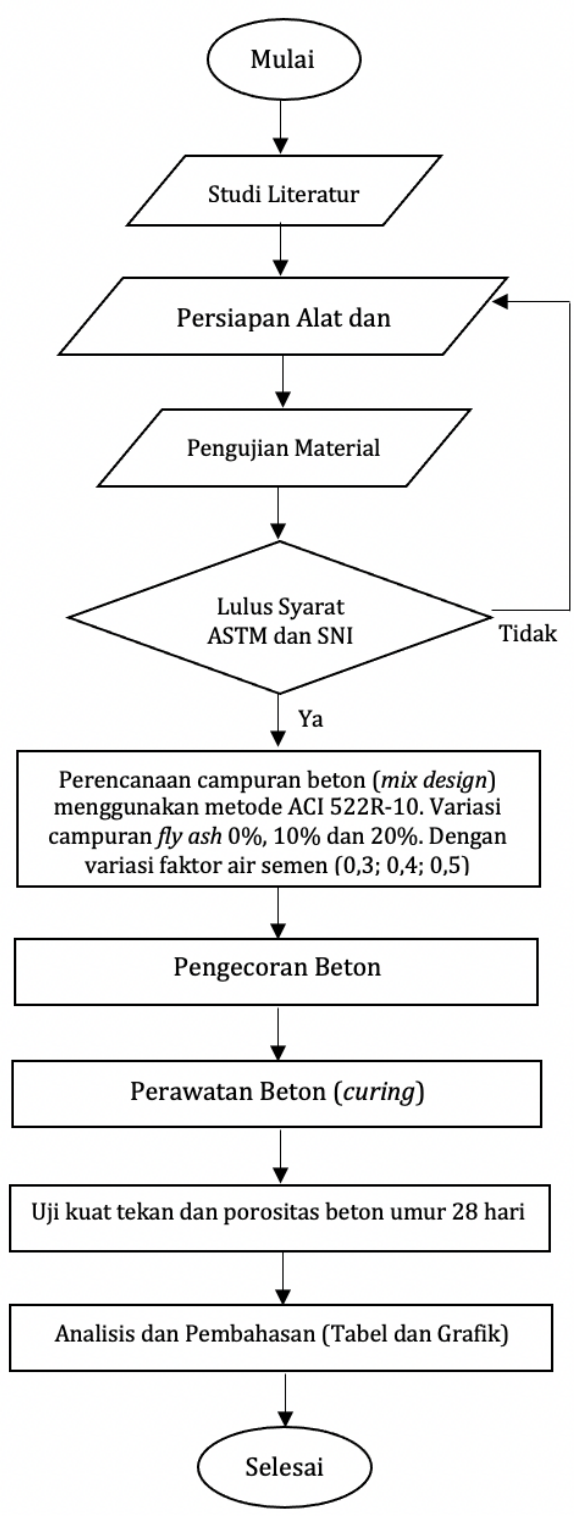

Gambar 1. Bagan Alir Penelitian

\section{Pengujian Material}

Pengujian pada tahap ini dilakukan pemeriksaan terhadap semen, agregat kasar, air, fly 
ash, dan peralatan. Pengujian material ini bertujuan untuk mengetahui apakah material tersebut memenuhi persyaratan yang telah ditentukan dari segi sifat dan karakteristik sebagai bahan campuran sesuai standar yang telah ditetapkan. Hasil dari pengujian ini akan digunakan sebagai data dalam pembuatan rancangan campuran beton [7].

1. Pengujian semen meliputi percobaan waktu ikat semen, pengujian berat jenis semen sesuai standar [8], pemeriksaan tanggal produksi semen untuk mengetahui lamanya penyiMPanan semen sebelum dibeli, tidak ada guMPalan atau semen padat, semen yang masih baik akan mengapung/mengambang sejenak sebelum mengendap saat ditabur diatas permukaan air.

2. Pengujian agregat kasar meliputi pemeriksaan kadar air agregat kasar [9], pemeriksaan berat jenis dan penyerapan agregat kasar [10], analisis saringan [11], pemeriksaan berat volume agregat kasar [12].

3. Pengujian agregat kasar meliputi pemeriksaan air dilakukan dengan cara visual / kasat mata yaitu air harus taMPak jernih, tidak mengandung lumpur, dan tidak berbau agar tidak mempengaruhi kualitas beton [13].

4. Pengujian fly ash bisa dilihat secara kasat mata. Fly ash yang baik memiliki ciri-ciri berwarna keabu-abuan dan berbutir halus

5. Pemeriksaan peralatan, bertujuan untuk memastikan ketika penelitian dilakukan peralatan yang digunakan dapat bekerja dengan baik dan tidak rusak

Adapun hasil dari pemeriksaan material yang dilakukan disajikan pada Tabel 1. Pada pemeriksaan material dapat disimpulkan bahwa material memenuhi persyaratan yang telah ditetapkan.

Tabel 1. Properti Material

\begin{tabular}{lll}
\hline Material & \multicolumn{1}{c}{ Properti Material } \\
\hline Semen & Tipe & 1 \\
& Waktu ikat & 110 menit \\
\hline $\begin{array}{lll}\text { Agregat } \\
\text { Kasar }\end{array}$ & Apparent Specific Gravity & $2,72 \mathrm{gr} / \mathrm{cm}^{3}$ \\
& $\begin{array}{l}\text { Bulk Specific Gravity Kondisi } \\
\text { Kering }\end{array}$ & $2,54 \mathrm{gr} / \mathrm{cm}^{3}$ \\
& Bulk Specific Gravity Kondisi SSD & $2,61 \mathrm{gr} / \mathrm{cm}^{3}$ \\
& $\begin{array}{l}\text { Persentase Penyerapan } \\
\text { (Absorbtion) }\end{array}$ & $2,72 \%$ \\
& Modulus Halus & 7,64 \\
\hline Fly Ash & Pengayakan & Saringan 50 \\
\hline
\end{tabular}

\section{Perencanaan Campuran Beton}

Perecanaan komposisi campuran beton ( $m i x$ design) mengacu pada [14]. Mutu beton yang di rencanakan pada penelitian ini mengacu pada standar mutu bata beton yaitu $10 \mathrm{MPa}$. Ukuran agregat kasar maksimum adalah $20 \mathrm{~mm}$.
Penggunaan fly ash yaitu dengan variasi $0 \%, 10 \%$, dan $20 \%$ dari berat semen dan faktor air semen (FAS) dengan variasi $0,3,0,4$,dan 0,5. Didapat komposisi campuran beton untuk 4 buah silinder seperti tabel sebagai berikut:

Tabel 2. Kebutuhan Komposisi Campuran 4 buah Silinder

\begin{tabular}{|c|c|c|c|c|c|c|c|c|c|}
\hline \multirow{2}{*}{$\begin{array}{c}\text { Material } \\
\text { (kg) }\end{array}$} & \multicolumn{9}{|c|}{ FAS (Faktor Air Semen) } \\
\hline & \multicolumn{3}{|c|}{0,3} & \multicolumn{3}{|c|}{0,4} & \multicolumn{3}{|c|}{0,5} \\
\hline Air & 1,54 & 1,54 & 1,54 & 1,55 & 1,55 & 1,55 & 1,56 & 1,56 & 1,56 \\
\hline Semen & 4 & 3,6 & 3,2 & 3,33 & 2,7 & 2,4 & 2,4 & 2,2 & 1,92 \\
\hline Fly ash & $0 \%$ & $10 \%$ & $20 \%$ & $0 \%$ & $10 \%$ & $20 \%$ & $0 \%$ & $10 \%$ & $20 \%$ \\
\hline & 0 & 0,4 & 0,8 & 0 & 0,3 & 0,6 & 0 & 0,22 & 0,48 \\
\hline Agregat & 27 & 27 & 26,97 & 27,6 & 27,5 & 27,5 & 27,9 & 27,9 & 27,6 \\
\hline
\end{tabular}

\section{Pembuatan Beton}

Langkah-langkah pembuatan beton yang pertama adalah mempersiapkan bahan-bahan yang dibutuhkan. Menimbang terlebih dahulu bahanbahan untuk pembuatan, sesuai dengan komposisi yang telah ditentukan dari hasil perhitungan mix design. Agregat kasar disaring terlebih dahulu dengan menggunakan saringan diameter $25 \mathrm{~mm}, 19$ $\mathrm{mm}, 9,5 \mathrm{~mm}, 4,75 \mathrm{~mm}$.

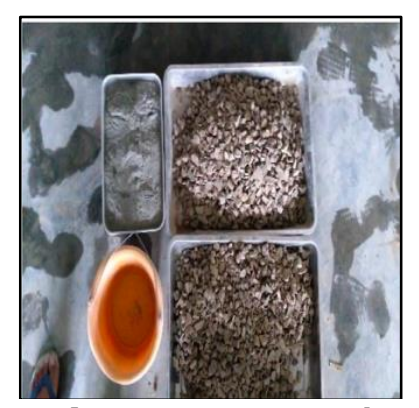

Gambar 2. Persiapan Bahan

Bahan-bahan yang telah ditimbang sebelumnya sesuai dengan komposisi yang telah direncanakan selanjutnya yaitu melakukan pencampuran bahan secara bertaha-tahap dimulai dengan memasukan aggregat kasar, kemudian semen dan fly ash lalu putar molen sambil memasukan air dikit demi sedikit hingga tercampur merata. Pengadukan campuran beton dilakukan satu kali untuk setiap variasi campuran.

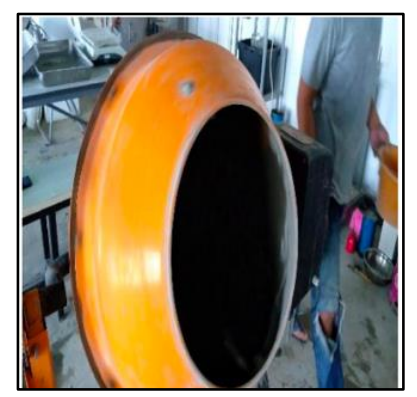

Gambar 3. Pencampuran Beton

Selanjutnya adalah pengujian slump test. Pengujian slump test bertujuan untuk mengetahui konsistensi (kekentalan adukan beton) pada adukan 
beton yang masih segar. Langkah kerja pada pengujian nilai slump adalah menggunakan kerucut abrams yang diletakan pada pelat baja. Adukan beton segar dimasukan kedalam kerucut saMPai mengisi $1 / 3$ dari tinggi kerucut lalu dilakukan pemadatan dengan tongkat besi sebanyak $25 \mathrm{kali}$ [15]. Kemudian ditambahkan lagi adukan beton segar saMPai terisi 2/3 dari tinggi kerucut, dipadatkan lagi mengunakan tongkat besi sebanyak 25 kali, selanjutnya dimasukan lagi adukan beton segar saMPai kerucut terisi penuh, dipadatkan lagi menggunakan tongkat besi sebanyak 25 kali. Masukan beton segar dan ratakan permukaan atas pada kerucut. Selanjutnya kerucut diangkat ke atas secara perlahan, setelah terjadinya runtuhan pada beton segar maka tentukan nilai slump dengan cara mengukur perbedaan tinggi antara kerucut abrams dengan adukan beton segar yang telah runtuh.

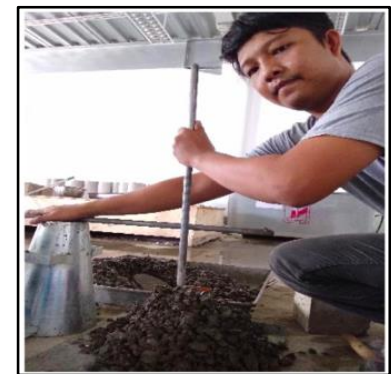

Gambar 4. Pengujian Slump Test

Setelah pengujian slump test, tahapan selanjutnya adalah pencetakan beton. Proses pencetakan beton dengan cara memasukan adukan beton segar kedalam cetakan silinder yang telah dipersiapkan. Dalam proses memasukan campuran ke dalam cetakan dibagi tiga lapisan pertama $1 / 3$ dari tinggi cetakan, kedua $2 / 3$ dari tinggi cetakan, dan terakhir cetakan diisi penuh dengan melakukan pematan pada setiap lapisan berupa ditumbuk sebanyak 25 kali menggunakan tongkat besi.

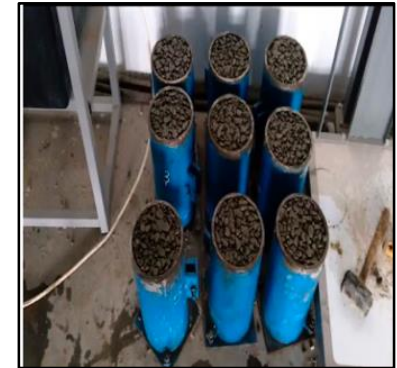

Gambar 5. Pencetakan Beton

Setelah dicetak, adukan beton kemudian dipadatkan. Proses pemadatan adukan beton dilakukan dengan dua cara, yaitu: pemadatan dengan menggunakan alat tongkat besi yang ditumbuk kedalam adukan beton dan pemadatan eksternal dengan cara menggetarkan cetakan beton silinder secara manual yaitu memukul sisi luar cetakan silinder dengan palu karat.

Setelah adukan beton dimasukan kedalam cetakan silinder maka beton dibiarkan selama 24 jam dan beton dapat dilepaskan dari cetakan. Maka selanjutnya beton diberi keterangan sampel.

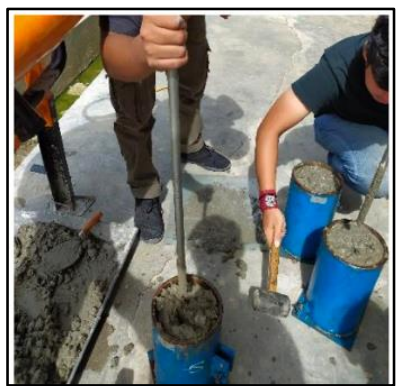

Gambar 6. Pemadatan Adukan Beton

\section{Curing Beton}

Tujuan pelaksanaan curing/perawatan beton adalah memastikan reaksi hidrasi senyawa semen termasuk bahan tambahan supaya dapat berlangsung secara optimal sehingga mutu beton yang diharapkan dapat tercapai, dan menjaga supaya tidak terjadi susut yang berlebihan pada beton akibat kehilangan kelembaban yang terlalu cepat atau tidak seragam, sehingga dapat menyebabkan retak pada beton.

Pelaksanaan curing/perawatan beton dilakukan segera setelah beton mengalami atau memasuki face hardening (untuk permukaan beton yang terbuka) atau setelah pelepasan cetakan, selama durasi tertentu yang dimaksudkan untuk memastikan terjaganya kondisi yang diperlukan untuk reaksi senyawa kimia yang terkandung dalam campuran beton [16].

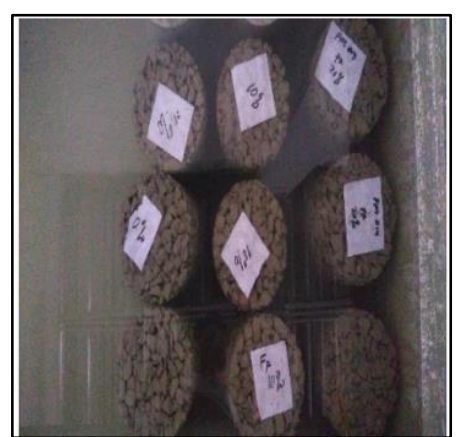

Gambar 7. Curing / Perawatan Beton

\section{HASIL DAN DISKUSI}

\section{Pengujian Benda Uji}

Pengujian yang dilakukan pada beton dalam penelitian ini dengan pengujian kuat tekan beton dan porositas beton yang dilakukan pada benda uji silinder setelah berumur 28 hari.

Pengujian dapat dilakukan setelah kondisi beton benar benar kering pada umur beton yang direncanakan. Sebelum pengujian kuat tekan dimulai, dilakukan penimbangan terhadap benda uji beton, setelah itu dilanjutkan dengan pelaksanaan capping menggunakan bahan belerang pada permukaan beton yang tidak rata. Capping bertujuan untuk meratakan permukaan beton, agar 
saat dilakukan uji kuat tekan diperoleh hasil yang maksimum.

Pengujian kuat tekan beton terhadap benda uji menggunakan mesin uji kuat tekan Compression Testing Machine (CTM) sesuai dengan peraturan [17]. Letakan benda uji pada mesin uji kuat tekan secara sentries, kemudian operasikan mesin uji dengan kecepatan penambahan beban yang konstan berkisar antara 2 saMPai $4 \mathrm{~kg} / \mathrm{cm} 2$ per detik. Lakukan pembacaan pembebanan saat kondisi beton hancur (dalam satuan ton atau $\mathrm{kN}$ ). Hasil kuat tekan benda uji dicatat saat jarum penunjuk kuat tekan mencapai nilai tertinggi. Berikut rumus untuk mencari nilai kuat tekan beton:

$$
f c^{\prime}=\frac{\mathrm{P}}{A}
$$

Dimana:

$\mathrm{fc}^{\prime}=$ kuat tekan silinder beton ( $\mathrm{MPa}$ atau $\mathrm{kg} / \mathrm{cm}^{2}$ ) $\mathrm{P}=$ beban maksimum saMPai beton hancur $(\mathrm{kg}, \mathrm{N})$

$\mathrm{A}=$ luas penaMPang silinder $\left(\mathrm{cm}^{2}, \mathrm{~mm}^{2}\right)$

Pengujian porositas beton dapat dilakukan setelah kondisi beton benar benar kering pada umur beton yang direncanakan. Sebelum pengujian porositas dimulai, dilakukan penimbangan terhadap benda uji beton, kemudian metode yang digunakan mengacu pada peraturan [14] yang telah di modifikasi seperti gambar dibawah ini :

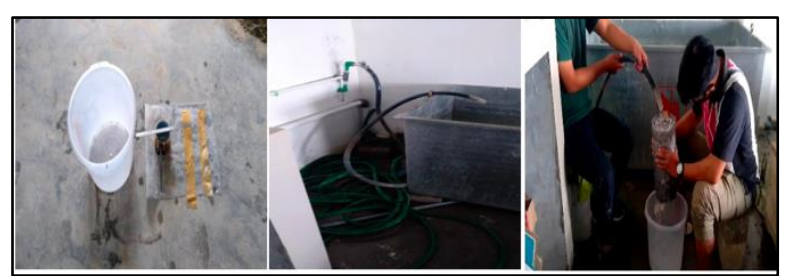

Gambar 8. Alat Uji Porositas yang telah Dimodifikasi

\section{Analisis Hasil Penelitian}

Analisis hasil dari penelitian ini dilakukan dengan cara menghitung kuat tekan dan porositas beton berpori menggunakan persamaan (1) dan disajikan dalam bentuk hasil percobaan dengan tabel dan grafik, kemudian mengetahui ada tidaknya pengaruh dari variabel yang digunakan terhadap kuat tekan dan porositas beton berpori dengan komposisi fly ash yang bervariasi dalam bentuk grafik.

Hasil pengujian dari 36 buah sampel berbentuk silinder yang masing-masing 27 sampel di uji kuat tekan dan 9 sampel di uji porositas dengan 9 variasi yaitu faktor air semen $(0,3 ; 0,4$ $0,5)$ dan fly ash (0\%,10\%, 20\%). Pengujian kuat tekan pada saat benda uji berumur 28 hari denggan menggunakan Compression Testing Machine (CTM).

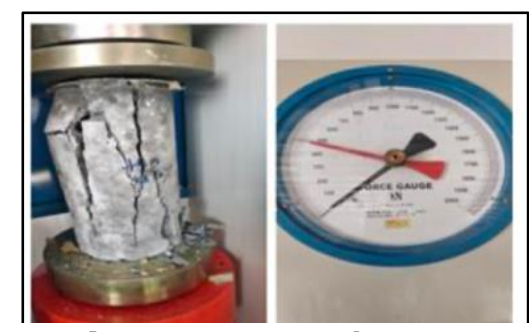

Gambar 9. Pengujian dengan CTM

1. Variasi 1 faktor air semen dan fly ash (FAS: 0,3 FA: 0\%)

Pada variasi faktor air semen 0,3 dan fly ash 0\% didapatkan berat rata-rata sebesar 9,515 kg dengan hasil kuat tekan beton 7,001 MPa. Terdapat pada Tabel 3 .

Tabel 3. Data Hasil Pengujian dengan Variasi 1

\begin{tabular}{ccc}
\hline \multirow{2}{*}{$\begin{array}{l}\text { Berat Beton } \\
\text { Silinder (kg) }\end{array}$} & \multicolumn{2}{c}{ Hasil Uji Kuat Tekan (MPa) } \\
\cline { 2 - 3 } & Kn & MPa \\
\hline 9,367 & 126 & 7,134 \\
\hline 9,536 & 125 & 7,077 \\
\hline 9,643 & 120 & 6,794 \\
\hline Kuat Tekan Rata-rata & & 7,002 \\
\hline
\end{tabular}

2. Variasi 2 faktor air semen dan fly ash (FAS: 0,3 FA: $10 \%)$

Pada variasi faktor air semen 0,3 dan fly ash 10\% didapatkan berat rata-rata sebesar 9,319 kg dengan hasil kuat tekan beton 5,472 MPa. Terdapat pada Tabel 4 .

Tabel 4. Data Hasil Pengujian dengan Variasi 2

\begin{tabular}{ccc}
\hline $\begin{array}{l}\text { Berat Beton } \\
\text { Silinder (kg) }\end{array}$ & \multicolumn{2}{c}{ Hasil Uji Kuat Tekan (MPa) } \\
\cline { 2 - 3 } & Kn & MPa \\
\hline 9,145 & 100 & 5,662 \\
\hline 9,284 & 95 & 5,379 \\
\hline 8,988 & 95 & 5,379 \\
\hline Kuat Tekan Rata-rata & & 5,473 \\
\hline
\end{tabular}

3. Variasi 3 faktor air semen dan fly ash (FAS: 0,3 FA: 20\%)

Pada variasi faktor air semen 0,3 dan fly ash $20 \%$ didapatkan berat rata-rata sebesar 8,929 kg dengan hasil kuat tekan beton 3,869 MPa. Terdapat pada Tabel 5 .

Tabel 5. Data Hasil Pengujian dengan Variasi 3

\begin{tabular}{ccc}
\hline $\begin{array}{l}\text { Berat Beton } \\
\text { Silinder (kg) }\end{array}$ & \multicolumn{2}{c}{ Hasil Uji Kuat Tekan (MPa) } \\
\cline { 2 - 3 } & Kn & MPa \\
\hline 8,736 & 70 & 3,963 \\
\hline 8,992 & 70 & 3,963 \\
\hline 9,061 & 65 & 3,680 \\
\hline Kuat Tekan Rata-rata & & 3,869 \\
\hline
\end{tabular}


4. Variasi 4 faktor air semen dan fly ash (FAS: 0,4 FA: $0 \%)$

Pada variasi faktor air semen 0,4 dan fly ash $0 \%$ didapatkan berat rata-rata sebesar 9,056 kg dengan hasil kuat tekan beton 5,662 MPa. Terdapat pada Tabel 6.

Tabel 6. Data Hasil Pengujian dengan Variasi 4

\begin{tabular}{ccc}
\hline $\begin{array}{l}\text { Berat Beton } \\
\text { Silinder (kg) }\end{array}$ & \multicolumn{2}{c}{ Hasil Uji Kuat Tekan (MPa) } \\
\cline { 2 - 3 } 9,255 & Kn & MPa \\
\hline 8,974 & 95 & 6,228 \\
\hline 8,941 & 95 & 5,379 \\
\hline Kuat Tekan Rata-rata & & 5,379 \\
\hline
\end{tabular}

5. Variasi 5 faktor air semen dan fly ash (FAS: 0,4 FA: $10 \%)$

Pada variasi faktor air semen 0,4 dan fly ash $10 \%$ didapatkan berat rata-rata sebesar 8,826 kg dengan hasil kuat tekan beton 4,152 MPa. Terdapat pada Tabel 7 .

Tabel 7. Data Hasil Pengujian dengan Variasi 5

\begin{tabular}{ccc}
\hline $\begin{array}{l}\text { Berat Beton } \\
\text { Silinder (kg) }\end{array}$ & \multicolumn{2}{c}{ Hasil Uji Kuat Tekan (MPa) } \\
\cline { 2 - 3 } & Kn & MPa \\
\hline 8,711 & 70 & 3,963 \\
\hline 8,838 & 76 & 4,303 \\
\hline 8,931 & 74 & 4,190 \\
\hline Kuat Tekan Rata-rata & & 4,152 \\
\hline
\end{tabular}

6. Variasi 6 faktor air semen dan fly ash (FAS: 0,4 FA: 20\%)

Pada variasi faktor air semen 0,4 dan fly ash $20 \%$ didapatkan berat rata-rata sebesar 8,535 kg dengan hasil kuat tekan beton 3,774 MPa. Terdapat pada Tabel 8.

Tabel 8. Data Hasil Pengujian dengan Variasi 6

\begin{tabular}{ccc}
\hline $\begin{array}{l}\text { Berat Beton } \\
\text { Silinder (kg) }\end{array}$ & \multicolumn{2}{c}{ Hasil Uji Kuat Tekan (MPa) } \\
\cline { 2 - 3 } 8,706 & Kn & MPa \\
\hline 8,699 & 70 & 3,680 \\
\hline 8,201 & 65 & 3,963 \\
\hline Kuat Tekan Rata-rata & & 3,680 \\
\hline
\end{tabular}

7. Variasi 7 faktor air semen dan fly ash (FAS: 0,5 FA: $0 \%)$

Pada variasi faktor air semen 0,5 dan fly ash $0 \%$ didapatkan berat rata-rata sebesar 8,815 kg dengan hasil kuat tekan beton 5,662 MPa. Terdapat pada Tabel 9.
Tabel 9. Data Hasil Pengujian dengan Variasi 7

\begin{tabular}{ccc}
\hline $\begin{array}{l}\text { Berat Beton } \\
\text { Silinder (kg) }\end{array}$ & \multicolumn{2}{c}{ Hasil Uji Kuat Tekan (MPa) } \\
\cline { 2 - 3 } & Kn & MPa \\
\hline 8,837 & 90 & 5,096 \\
\hline 8,684 & 110 & 6,228 \\
\hline 8,926 & 100 & 5,662 \\
\hline Kuat Tekan Rata-rata & & 5,662 \\
\hline
\end{tabular}

8. Variasi 8 faktor air semen dan fly ash (FAS: 0,5 FA: $10 \%)$

Pada variasi faktor air semen 0,5 dan fly ash $10 \%$ didapatkan berat rata-rata sebesar 8,734 kg dengan hasil kuat tekan beton 4,058 MPa. Terdapat pada Tabel 10.

Tabel 10.Data Hasil Pengujian dengan Variasi 8

\begin{tabular}{ccc}
\hline \multirow{2}{*}{$\begin{array}{l}\text { Berat Beton } \\
\text { Silinder (kg) }\end{array}$} & \multicolumn{2}{c}{ Hasil Uji Kuat Tekan (MPa) } \\
\cline { 2 - 3 } & Kn & MPa \\
\hline 8,760 & 65 & 3,680 \\
\hline 8,727 & 75 & 4,246 \\
\hline 8,717 & 75 & 4,246 \\
\hline Kuat Tekan Rata-rata & & 4,058
\end{tabular}

9. Variasi 9 faktor air semen dan fly ash (FAS: 0,5 FA: 20\%)

Pada variasi faktor air semen 0,5 dan fly ash $20 \%$ didapatkan berat rata-rata sebesar 8,661 kg dengan hasil kuat tekan beton 3,586 $\mathrm{MPa}$. Terdapat pada Tabel 11.

Tabel 11.Data Hasil Pengujian dengan Variasi 9

\begin{tabular}{ccc}
\hline $\begin{array}{l}\text { Berat Beton } \\
\text { Silinder (kg) }\end{array}$ & \multicolumn{2}{c}{ Hasil Uji Kuat Tekan (MPa) } \\
\cline { 2 - 3 } & Kn & MPa \\
\hline 8,672 & 65 & 3,680 \\
\hline 8,611 & 65 & 3,680 \\
\hline 8,701 & 60 & 3,397 \\
\hline Kuat Tekan Rata-rata & & 3,586 \\
\hline
\end{tabular}

\section{Pengaruh Fly Ash pada Kuat Tekan Beton Berpori}

1. Pengaruh fly ash terhadap kuat tekan beton berpori ditinjau dari FAS 0,3

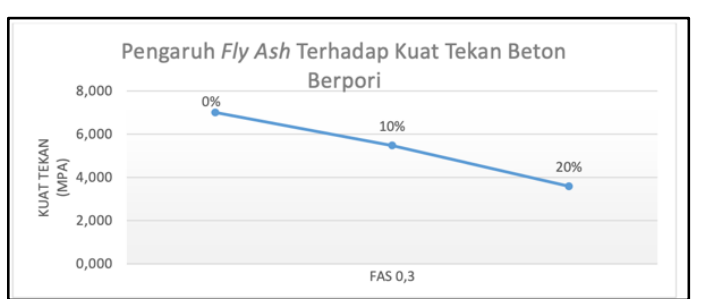

Gambar 10. Hasil Pengujian Kuat Tekan Beton Berpori FAS 0,3 
Didapat hasil secara berurutan $7 \mathrm{MPa}, 5,4 \mathrm{MPa}$, 3,8 MPa. Untuk nilai kuat tekan optimum didapat pada penambahan fly ash sebesar $10 \%$ dan menurun pada penambahan fly ash sebesar 20\%, semakin banyak penambahan fly ash pada beton, hasil kuat tekan umumnya lebih kecil.

2. Pengaruh fly ash terhadap kuat tekan beton berpori ditinjau dari FAS 0,4

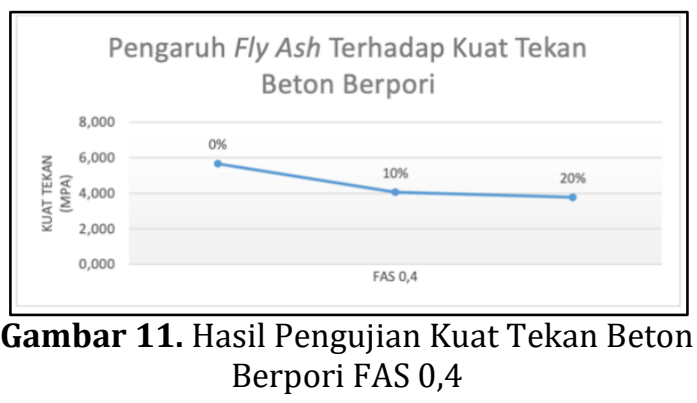

Didapat hasil secara berurutan 5,6 $\mathrm{MPa}, 4,1$ $\mathrm{MPa}, 3,7 \mathrm{MPa}$. Untuk nilai kuat tekan optimum didapat pada penambahan fly ash sebesar $10 \%$ dan menurun pada penambahan fly ash sebesar 20\%, semakin banyak penambahan fly ash pada beton, hasil kuat tekan umumnya lebih kecil.

3. Pengaruh fly ash terhadap kuat tekan beton berpori ditinjau dari FAS 0,5

Didapat hasil secara berurutan 5,6 $\mathrm{MPa}, 4 \mathrm{MPa}$, 3,5 MPa. Untuk nilai kuat tekan optimum didapat pada penambahan fly ash sebesar $10 \%$ dan menurun pada penambahan fly ash sebesar $20 \%$, semakin banyak penambahan fly ash pada beton, beton akan menjadi semakin ringan. Seperti dapat dilihat pada Gambar 3

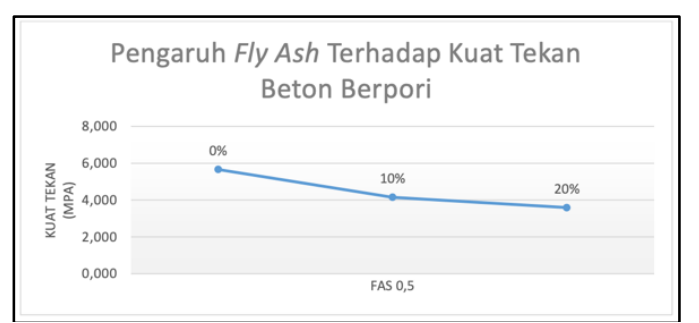

Gambar 12. Hasil Pengujian Kuat Tekan Beton Berpori FAS 0,5

\section{Pengaruh Faktor Air Semen pada Kuat Tekan Beton Berpori}

1. Pengaruh faktor air semen terhadap kuat tekan beton berpori ditinjau dari penambahan fly ash $0 \%$

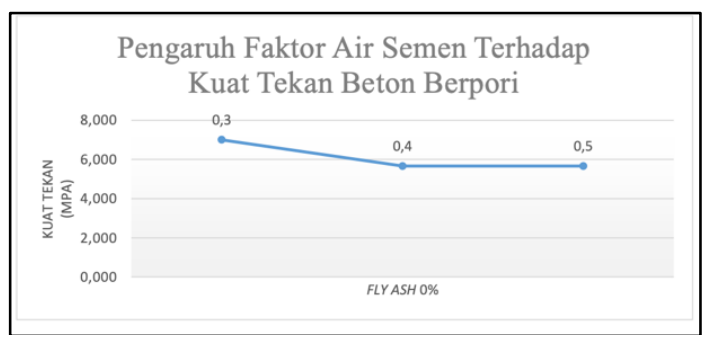

Gambar 13. Hasil Kuat Tekan Beton Berpori Fly Ash 0\%

Hasilnya didapat nilai kuat tekan sebesar 7 $\mathrm{MPa}$, 5,6 $\mathrm{MPa}$, 5,6 $\mathrm{MPa}$. Nilai kuat tekan optimum terdapat pada FAS 0,3

2. Pengaruh faktor air semen terhadap kuat tekan beton berpori ditinjau dari penambahan fly ash $10 \%$

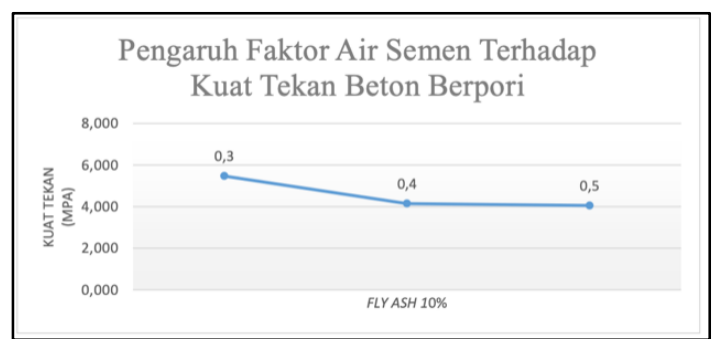

Gambar 14. Hasil Kuat Tekan Beton Berpori Fly Ash $10 \%$

Hasilnya didapat nilai kuat tekan sebesar 5,4 $\mathrm{MPa}, 4,1 \mathrm{MPa}, 4 \mathrm{MPa}$. Nilai kuat tekan optimum terdapat pada FAS 0,3 , hal ini menunjukkan bahwa faktor air semen memiliki pengaruh pada kuat tekan beton yang didapat. Hal ini juga dipengaruhi oleh nilai slump test karena semakin tinggi nilai slump maka semakin mengurangi kuat tekan beton tersebut.

3. Pengaruh faktor air semen terhadap kuat tekan beton berpori ditinjau dari penambahan fly ash $20 \%$

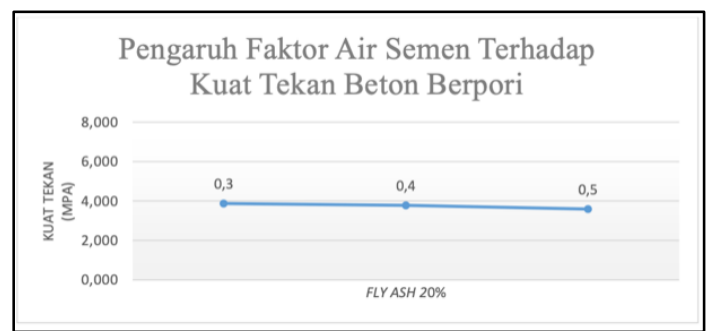

Gambar 15. Hasil Kuat Tekan Beton Berpori Fly Ash 20\%

Hasilnya didapat nilai kuat tekan sebesar 3,8 $\mathrm{MPa}, 3,7 \mathrm{MPa}, 3,5 \mathrm{MPa}$. Nilai kuat tekan optimum terdapat pada FAS 0,3. 


\section{Pengaruh Fly Ash pada Porositas Beton Berpori}

1. Pengaruh fly ash terhadap porositas beton berpori ditinjau dari FAS 0,3

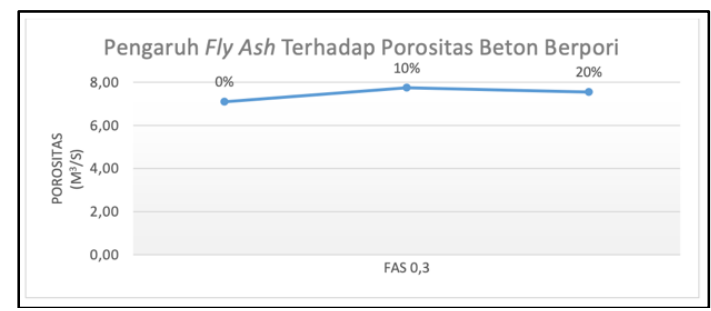

Gambar 16. Pengaruh Fly Ash terhadap Porositas Beton FAS 0,3

Hasil pengaruh fly ash terhadap porositas beton berpori didapat 7,10 $\mathrm{m}^{3} / \mathrm{s}, 7,75 \mathrm{~m}^{3} / \mathrm{s}$, $7,55 \mathrm{~m}^{3} / \mathrm{s}$. Untuk nilai porositas optimum pada penambahan fly ash sebesar $10 \%$ dan menurun pada penambahan fly ash sebesar $20 \%$.

2. Pengaruh fly ash terhadap porositas beton berpori ditinjau dari FAS 0,4

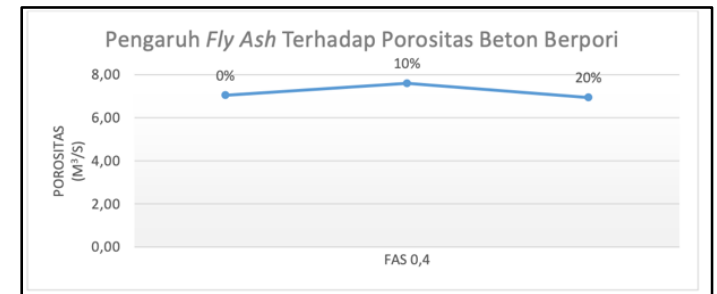

Gambar 17. Pengaruh Fly Ash terhadap Porositas Beton FAS 0,4

Hasil pengaruh fly ash terhadap porositas beton berpori didapat 7,05 $\mathrm{m}^{3} / \mathrm{s}, 7,60 \mathrm{~m}^{3} / \mathrm{s}$, $6,94 \mathrm{~m}^{3} / \mathrm{s}$. Untuk nilai porositas optimum pada penambahan fly ash sebesar $10 \%$ dan menurun pada penambahan fly ash sebesar 20\%. Hal ini terjadi karena semakin baiknya ikatan antara unsur penyusun beton, semakin banyak penggunaan fly ash maka semakin mengurangi pori yang ada pada beton sehingga menurunkan nilai porositas pada beton

3. Pengaruh fly ash terhadap porositas beton berpori ditinjau dari FAS 0,5

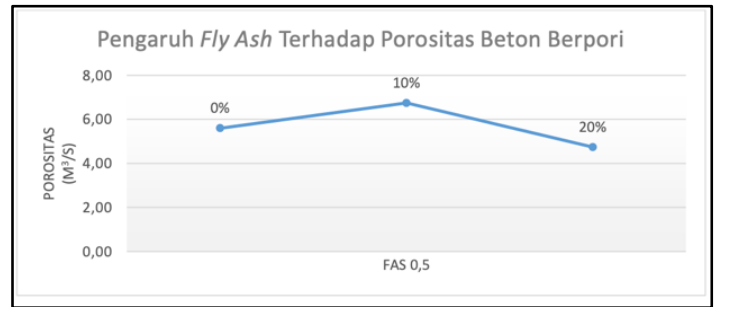

Gambar 18. Pengaruh Fly Ash terhadap Porositas Beton FAS 0,5

Hasil pengaruh fly ash terhadap porositas beton berpori didapat $6,41 \mathrm{~m}^{3} / \mathrm{s}, 6,70 \mathrm{~m}^{3} / \mathrm{s}$, $4,74 \mathrm{~m}^{3} / \mathrm{s}$. Untuk nilai porositas optimum pada penambahan fly ash sebesar $10 \%$ dan menurun pada penambahan fly ash sebesar $20 \%$.

\section{Pengaruh Faktor Air Semen pada Prositas Beton Berpori}

1. Pengaruh faktor air semen terhadap porositas beton berpori ditinjau dari penambahan fly ash $0 \%$

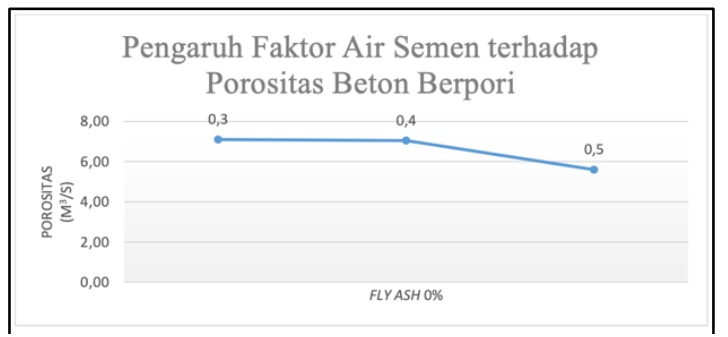

Gambar 19. Pengaruh FAS terhadap Porositas (fly ash 0\%)

Hasil pengaruh fly ash terhadap porositas beton berpori didapat $7,10 \mathrm{~m}^{3} / \mathrm{s}, 7,05 \mathrm{~m}^{3} / \mathrm{s}$, $5,60 \mathrm{~m}^{3} / \mathrm{s}$. Nilai kuat tekan optimum terdapat pada FAS 0,3, yang membuktikan semakin besar nilai FAS maka semakin menurun nilai porositas yang didapat.

2. Pengaruh faktor air semen terhadap porositas beton berpori ditinjau dari penambahan fly ash $10 \%$

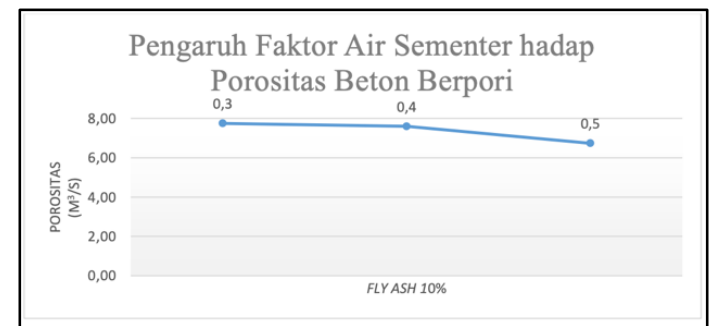

Gambar 20. Pengaruh FAS terhadap Porositas (fly ash 10\%)

Hasil pengaruh fly ash terhadap porositas beton berpori didapat 7,75 $\mathrm{m}^{3} / \mathrm{s}, 7,60 \mathrm{~m}^{3} / \mathrm{s}$, $6,74 \mathrm{~m}^{3} / \mathrm{s}$. Nilai kuat tekan optimum terdapat pada FAS 0,3 .

3. Pengaruh faktor air semen terhadap porositas beton berpori ditinjau dari penambahan fly ash $20 \%$

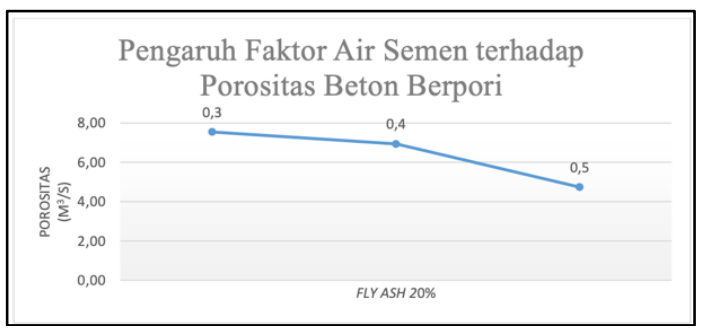

Gambar 21. Pengaruh FAS terhadap Porositas.

(fly ash 20\%)

Hasil pengaruh fly ash terhadap porositas beton berpori didapat 7,55 $\mathrm{m}^{3} / \mathrm{s}, 6,94 \mathrm{~m}^{3} / \mathrm{s}$, $4,74 \mathrm{~m}^{3} / \mathrm{s}$. Nilai kuat tekan optimum terdapat pada FAS 0,3, yang membuktikan semakin 
besar nilai FAS maka semakin menurun nilai porositas yang didapat.

\section{KESIMPULAN}

Pengaruh fly ash terhadap kuat tekan dan porositas beton berpori yang ditinjau dari variasi faktor air semen $0,3,0,4$, dan 0,5 yaitu semakin banyak penggunaan fly ash pada beton berpori, maka beton berpori tersebut menjadi lebih ringan dan dapat mengurangi rongga udara pada beton tersebut oleh karena itu kuat tekan dan porositas yang dihasilkan umumnya lebih kecil. Pengaruh faktor air semen terhadap kuat tekan dan porositas beton berpori yang ditinjau dari variasi fly ash $0 \%$, $10 \%$, dan $20 \%$ yaitu semakin besar nilai FAS maka semakin menurun nilai kuat tekan dan porositas beton berpori. Hal ini di pengaruhi oleh nilai slump test karena semakin tinggi nilai slump maka semakin mengurangi kuat tekan dan porositas beton tersebut. Kuat tekan beton berpori yang optimum ditinjau dari variasi faktor air semen didapat pada penggantian fly ash sebesar 10\% dengan FAS 0,3 nilai kuat tekan sebesar 5,47 MPa. Porositas beton berpori yang optimum ditinjau dari faktor air semen didapat pada variasi penggantian fly ash sebesar $10 \%$ dengan FAS 0,3 nilai porositas sebesar 7,75 m3/s.

\section{REFERENSI}

[1] N. U. Kockal and T. Ozturan, "Effects of lightweight fly ash aggregate properties on the behavior of lightweight concretes," J. Hazard. Mater., vol. 179, no. 1-3, pp. 954965, 2010, doi: 10.1016/j.jhazmat.2010.03.098.

[2] NRMCA, "Concrete in Practice CIP-38 Pervious Concrete," 2004.

[3] M. Franus, J. Panek Rafałand Madej, and W. Franus, "The properties of fly ash derived lightweight aggregates obtained using microwave radiation," Constr. Build. Mater., vol. 227, pp. 1-10, 2019, doi: 10.1016/j.conbuildmat.2019.116677.

[4] ASTM C150 / C150M - 20, "Standard Specification for Portland Cement," ASTM International, West Conshohocken, PA, 2020, www.astm.org.

[5] ASTM C125-20, "Standard Terminology Relating to Concrete and Concrete Aggregates," ASTM International, West Conshohocken, PA, 2020, www.astm.org.

[6] ASTM C33 / C33M - 18, "Standard Specification for Concrete Aggregates," ASTM International, West Conshohocken, PA, 2018, www.astm.org.

[7] J. O. Slmanjuntak, T. E. Saragi, F. H. Simbolon, K. Sirlngo-ringo, J. P. Sltanggang, and P. L. L.
Sianturi, "Hubungan Perawatan Beton dengan Kuat Tekanan (Pengujian Laboratorium)," J. Poliprofesi, vol. X, no. 1, July, 2015.

[8] ASTM C188-17, "Standard Test Method for Density of Hydraulic Cement," ASTM International, West Conshohocken, PA, 2017, www.astm.org.

[9] ASTM C566-19, "Standard Test Method for Total Evaporable Moisture Content of Aggregate by Drying," ASTM International, West Conshohocken, PA, 2019, www.astm.org.

[10] ASTM C127-15, "Standard Test Method for Density, Relative Density (Specific Gravity), and Absorption of Coarse Aggregate," ASTM International, West Conshohocken, PA, 2015, www.astm.org.

[11] ASTM C136 / C136M - 19, "Standard Test Method for Sieve Analysis of Fine and Coarse Aggregates," ASTM International, West Conshohocken, PA, 2019, www.astm.org.

[12] ASTM C29/C29M - 17a, "Standard Test Method for Bulk Density ('Unit Weight') and Voids in Aggregate, Manual of Aggregate amd Concrete Testing," ASTM International, West Conshohocken, PA, 2020, www.astm.org.

[13] Badan Standardisasi Nasional, SNI 2847: 2013 Persyaratan Beton Struktural untuk Bangunan Gedung, Jakarta: BSN, 2013.

[14] American Concrete Institute, ACI 522R-10 Report on Pervious Concrete, USA : ACI, 2010.

[15] Badan Standardisasi Nasional, SNI 1972:2008 Cara Uji Slump Beton, Jakarta: BSN, 2008.

[16] American Concrete Institute, ACI 308R-01 Guide to Curing Concrete, USA : ACI, 2001.

[17] ASTM C39/C39M - 20, "Standard Test Method for Compressive Strength of Cylindrical Concrete Specimens," ASTM International, West Conshohocken, PA, 2020, www.astm.org. 